\title{
Pemanfaatan Energi Surya untuk Penerangan Jalan \& Fasilitas Umum di Desa Sukarame Kab. Lebak Banten
}

\author{
Tri Wahyu Oktaviana Putri ${ }^{1}$; Adri Senen ${ }^{2}$; Yoakim Simamora ${ }^{3}$; Dwi Anggaini ${ }^{4}$ \\ 1,2,3,4 Teknik Elektro, Sekolah Tinggi Teknik PLN \\ triwahyu@sttpln.ac.id
}

\begin{abstract}
ABSTRAK
Jalan sebagai salah satu sarana umum yang vital dalam menghubungkan antar daerah satu ke daerah yang lainnya. Oleh karena itu, keberadaaan penerangan jalan umum (PJU) adalah hal yang sangat penting demi kelancaran aktivitas warga di malam hari. Tetapi, tidak semua ruas jalan telah terpasang PJU. Misalnya ruas jalan desa di Desa Sukarame, Kec. Sajira, Kab. Lebak, Banten. Desa ini merupakan desa yang dialiri arus listrik tetapi pasokan listrik untuk PJU masih sangat terbatas. Oleh karena itu diperlukan pemasangan PJU berupa lampu tenaga surya sebagai alternatif efektif bagi penerangan jalan dan fasilitas umum. Lampu tenaga surya dipilih mengingat lampu tersebut tidak memerlukan pasokan listrik dari rumah warga dan keadaan geografis desa yang sangat potensial untuk memanfaatkan energi surya. Lampu tenaga surya dipasang pada 3 titik strategis yaitu di jalan kampung depan TK, jalan kampung depan lapangan, dan teras mushola. Selain pemasangan lampu untuk penerangan umum, analisis ekonomi juga dilakukan pada kegiatan ini dengan cara membandingkan total biaya yang diperlukan PJU lampu surya dengan total biaya PJU lampu pijar. Walaupun harga PJU tenaga surya lebih mahal, tetapi untuk penggunaan jangka panjang, PJU tenaga surya jauh lebih ekonomis dibandingkan PJU lampu pijar, dengan selisih biayanya sebesar $R p$ 636.582,80 pertiang dalam jangka waktu pemakaian 3 tahun.
\end{abstract}

Kata kunci : Jalan, Lampu, Energi Surya

\begin{abstract}
Road is a vital public facility that connects one region to another region. Hence, the existence of public street lighting is a key to supports people's activities at night. But not all roads are equipped with public street lighting. For example, the village roads in Sukarame Village, Sajira sub-district, Lebak regency, Banten. This village is fully electrified but the supply for public street lighting is still limited. Therefore, it is neccesary to install public street lighting in the form of solar lamps as an effective alternative for street lighting and public facilities. Solar lamp is chosen because it doesn't need power supply and the village's geographical is very potential for utilizing solar lamps. Solar lamps installed in 3 strategic points, which are village road in front of local kindergarten, village road in front of public field, and mosque's terrace. Besides solar lamp installation, this research also focused in economic analysis of this program. The analysis was done by comparing total cost needed for conventional public street lighting using bulbs that connect to grid with total cost needed for public street lighting using solar lamps. Despite solar lamp's price is more expensive, for the long-term usage, public street lighting using solar lamps is more economically profitable compared to conventional public street lighting with the cost difference of Rp 636,582.80 per lamppost for 3 years usage period.
\end{abstract}

Keywords : Street, Lamps, Solar lamps 


\section{PENDAHULUAN}

Setiap tahunnya, kebutuhan energi listrik semakin meningkat. Di Indonesia sendiri, proyeksi pertumbuhan kebutuhan listrik mencapai 6,86\% setiap tahunnya [1]. Naiknya kebutuhan listrik dapat diartikan sebagai naiknya kebutuhan akan minyak dan gas bumi sebagai bahan bakar utama pembangkit listrik yang ada di Indonesia. Padahal minyak dan gas bumi berasal dari fosil yang jumlahnya terbatas dan memiliki efek samping. Apabila dalam waktu dekat tidak ditemukan sumbersumber energi baru yang signifikan pada tahun 2046 mendatang dikhawatirkan Indonesia akan mengalami defisit energi [2].

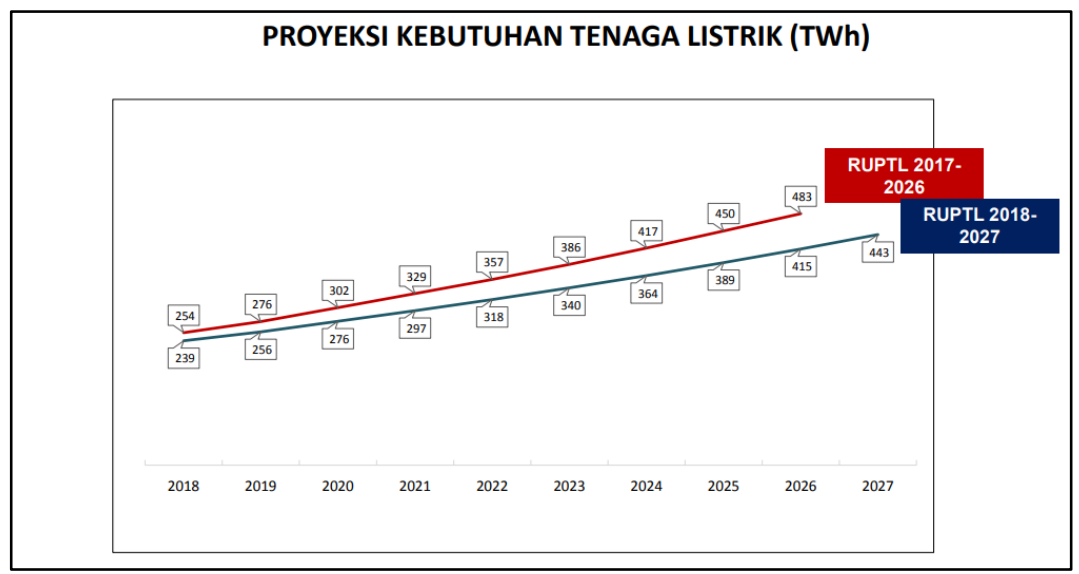

Gambar 1. Proyeksi Kebutuhan Tenaga Listrik [3]

Semakin meningkatnya kebutuhan tenaga listrik di Indonesia harus dibarengi dengan naiknya rasio elektrifikasi. Rasio elektrifikasi Indonesia pada tahun 2018 adalah sebesar 95,15\% [3]. Sedangkan jika dilihat perprovinsi, nilai rasio elektrifikasi bervariasi satu dengan yang lainnya. Contohnya rasio elektrifikasi di Provinsi Banten pada tahun 2018 adalah sebesar 98,93\% [3]. Angka tersebut cukup besar, akan tetapi pada kenyataannya masyarakat Banten, khusunya Kabupaten Lebak, masih mengeluhkan kurangnya penerangan jalan dan fasilitas umum di daerah mereka

PT.PLN (Persero) telah melakukan berbagai upaya untuk mengatasi peningkatan kebutuhan listrik dan menambah rasio elektrifikasi di Provinsi Banten, khusunya daerah Banten Selatan. PT PLN (Persero) menilai kebutuhan penambahan daya listrik di bagian Banten Selatan di dua kabupaten, khususnya Pandeglang dan Lebak, sangat mendesak [4]. Salah satu desa yang terletak di Kabupaten Lebak adalah Desa Sukarame. Desa ini merupakan desa yang terletak $80 \mathrm{~km}$ dari ibukota DKI Jakarta. Walaupun desa tersebut sudah teraliri listrik dan hanya berjarak $80 \mathrm{~km}$ dari ibukota, tetapi masih banyak ruas jalan, khususnya jalan-jalan desa yang tidak terpasang penerangan jalan umum (PJU). Permintaan pemasangan PJU telah lama diusulkan oleh pemerintah desa setempat kepada pihak terkait tetapi sampai saat ini belum ada tindak lanjut pemasangan PJU. Kurangnya ketersediaan lampu JPU berkaitan dengan daya tersambung untuk PJU di Provinsi Banten hanya sekitar $0,35 \%$ untuk data tahun 2015 [5].

Mayoritas penduduk di Desa Sukarame berprofesi sebagai petani dan penggarap lahan. Umumnya, masyarakat tidak tahu alternatif untuk PJU selain memasang lampu dengan menarik kabel listrik dari rumah warga. Padahal ada alternatif lain yang lebih efektif, ramah lingkungan, dan hemat biaya, yaitu memanfaatkan energi cahaya matahari untuk PJU. Matahari adalah sumber energi utama yang memancarkan energi yang luar biasa besarnya ke permukaan bumi. Pada keadaan cuaca 
cerah, permukaan bumi menerima sekitar 1000 watt energi matahari per-meter persegi. Kurang dari $30 \%$ energi tersebut dipantulkan kembali ke angkasa, 47\%dikonversikan menjadi panas, 23\% digunakan untuk seluruh sirkulasi kerja yang terdapat di atas permukaan bumi, sebagaian kecil 0,25\% ditampung angin, gelombang dan arus dan masih ada bagian yang sangat kecil 0,025\% disimpan melalui proses fotosintesis di dalam tumbuh-tumbuhan [6].

Untuk wilayah Indonesia, berdasarkan data penyinaran matahari yang dihimpun dari 18 lokasi yang berbeda, radiasi surya di Indonesia dapat diklasifikasikan berturut-turut sebagai berikut: untuk kawasan barat dan timur Indonesia dengan distribusi penyinaran di Kawasan Barat Indonesia (KBI) sekitar 4,5 kWh/m $\mathrm{m}^{2} /$ hari dengan variasi bulanan sekitar 10\%; dan di Kawasan Timur Indonesia (KTI) sekitar $5,1 \mathrm{kWh} / \mathrm{m}^{2} /$ hari dengan variasi bulanan sekitar $9 \%$. Dengan demikian, potesi penyinaran matahari rata-rata Indonesia sekitar $4,8 \mathrm{kWh} / \mathrm{m}^{2} /$ hari dengan variasi bulanan sekitar $9 \%$ [7].

Intensitas cahaya matahari di wilayah tersebut tergolong bagus sehingga memungkinkan untuk pemasangan lampu jalan tenaga surya. Beberapa ruas jalan menuju desa telah terdapat lampu PJU tenaga surya. Tetapi menurut warga sekitar, lampu tersebut telah lama tidak berfungsi. Berdasarkan pengamatan tim, lampu PJU tenaga surya yang berdiri tidak dapat bekerja karena baterai (aki) tidak ada.

Permasalahan minimnya lampu PJU dan fasilitas umum di Desa Sukarame menggerakkan dosen-dosen STT-PLN Jakarta untuk membantu mengatasi permasalahan tersebut. Dengan kegiatan Pengabdian Kepada Masyarakat (PKM), tim PKM dan penduduk desa bersama-sama memasang lampu PJU dan lampu untuk fasilitas umum dengan menggunakan lampu tenaga surya. Lampu tenaga surya dipilih karena pemasangannya mudah, awet, dan hemat. Masyarakat tidak perlu mengulur kabel dari rumah mereka atau jaringan PLN untuk menghidupkan lampu tenaga surya. Selain itu untuk menghindari pencurian baterai PJU tenaga surya seperti yang terjadi pada lampu PJU tenaga surya yang sudah terpasang sebelumnya, tim PKM memilih untuk menggunakan lampu tenaga surya dengan baterai tertanam (embedded battery). Lampu PJU yang dipasang oleh tim PKM juga memiliki sistem penyalaan otomatis saat sekelilingnya tidak terdapat cahaya.

\section{METODE}

\subsection{Sifat dan Bentuk Kegiatan}

Program Kemitraan Masyarakat dengan tema "Pemanfaatan Energi Surya di Desa Sukarame, Kab. Lebak, Banten dilaksanakan sekurang-kurangnya 4 hari kerja yaitu dengan memasang \pm 6 lampu surya dibeberapa titik jalan \& fasilitas umum. Berdasarkan survei lapangan, dipilih tempattempat strategis yang paling membutuhkan penerangan dengan syarat tempat tersebut menerima sinar matahari dengan optimal di siang hari. Titik pemasangan lampu adalah sebanyak 3 titik, yaitu jalan kampung depan TK, jalan kampung depan lapangan, dan teras mushola warga. Masing-masing dipasang 2 buah lampu tenaga surya. Lampu yang digunakan adalah lampu tenaga surya dengan panel surya 5 watt, 24 lampu LED, sistem penyalaan otomatis, dan baterai tertanam sebesar 2000 mAh. Langkah-langkah yang harus dilakukan untuk pelaksanaan kegiatan adalah:

Langkah 1 : Tim menyiapkan beberapa lampu surya dan instalasi yang dibutuhkan.

Langkah 2 : Setelah disiapkan tim dan warga akan memang lampu tersebut di beberapa titik yang telah ditentukan.

Langkah 3 : Setiap lampu akan diuji kekuatan baterai dan panel guna mengetahui kinerja lampu surya tersebut. 


\subsection{Diagram Alir Kegiatan}

Diagram alir kegiatan dapat dilihat pada Gambar 2 berikut ini.

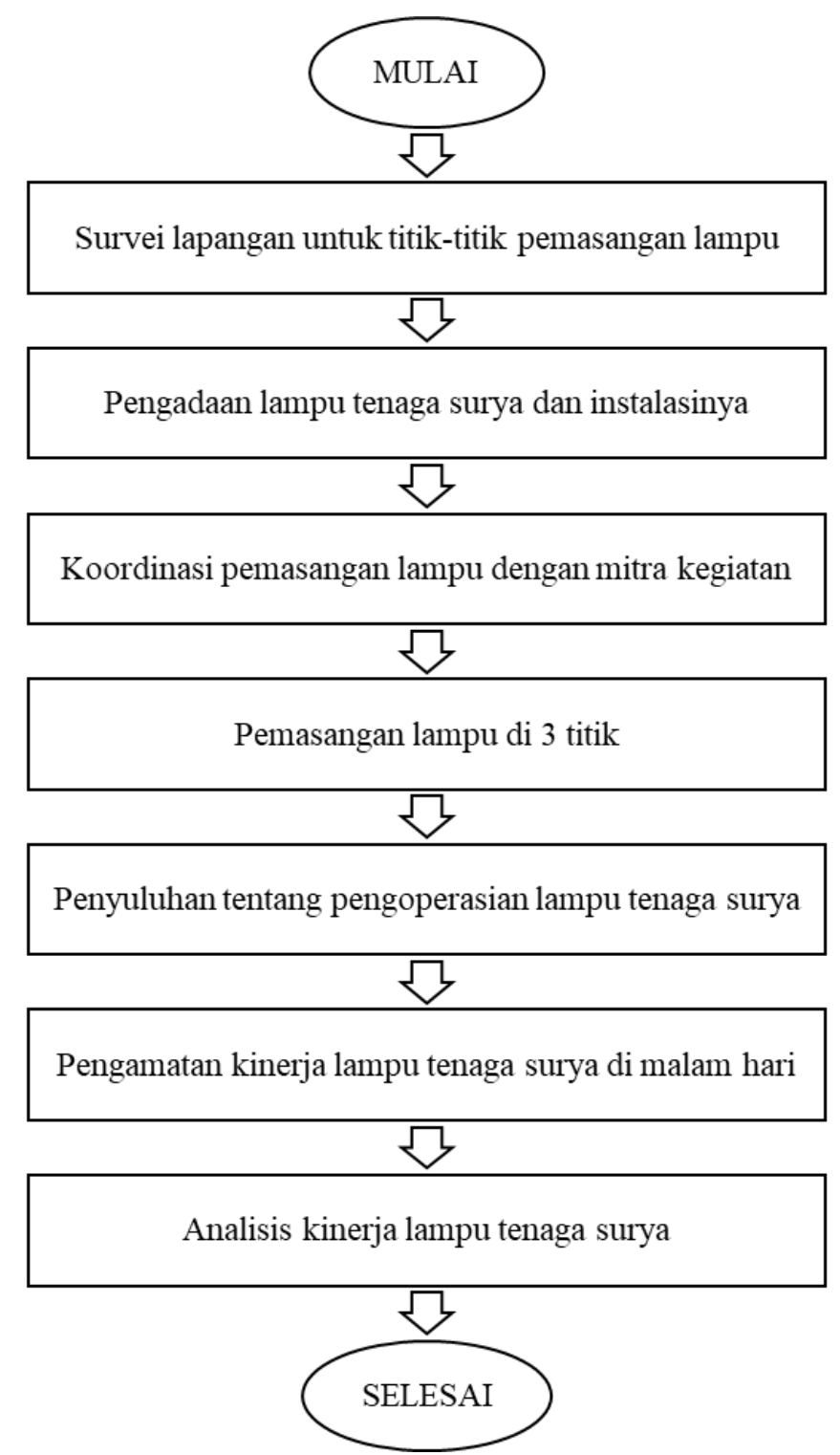

Gambar 2. Diagram Alir Kegiatan Pengabdian Kepada Masyarakat

\section{HASIL DAN PEMBAHASAN}

\subsection{Kegiatan Lapangan}

Lampu surya yang dipasang merupakan lampu 24 LED tenaga surya dengan baterai tertanam sebesar 2000mAh dan sistem penyalaan otomatis. Tipenya adalah Lampu KEIBU PJU LED 5 watt. Lampu ini juga memiliki panel surya sebesar 5 watt. Lampu dilengkapi sensor cahaya yang dapat mendeteksi ada tidaknya cahaya. Sensor tersebut yang akan memicu penyalaan lampu otomatis jika cahaya di sekelilingnya gelap/ redup. Sebaliknya, lampu akan padam otomatis jika terdapat cahaya. Artinya lampu surya ini dapat menyala otomatis ketika matahari sudah terbenam dan dapat mati otomatis saat matahari terbit, selama berfungsi normal. 
Berdasarkan uji coba sebelum pemasangan dengan keadaan baterai terisi penuh, lampu dapat menyala dengan cahaya maksimal selama kurang lebih 5 jam. Kemudian cahaya lampu akan semakin redup hingga lampu padam akibat kapasitas baterai kosong. Total waktu lampu dapat menyala adalah selama 12 jam. Jarak optimal penyinaran lampu ke tanah adalah 3 meter. Lebih dari itu, cahaya lampu kurang terang. Dari segi ketahanan, lampu ini memiliki ketahanan terhadap air hujan sehingga dapat diletakkan di luar ruangan (outdoor). Dimensi tidak terlalu besar, yaitu $12,5 \mathrm{~cm} \times 20 \mathrm{~cm}$. Pemasangannya pun mudah karena lampu sudah dilengkapi dengan mur, baut, pelat besi, dan batang ekstensi lampu. Dengan demikian dapat ditarik kesimpulan bahwa lampu surya KEIBU PJU LED 5W cukup baik untuk digunakan sebagai lampu penerangan di jalan-jalan kampung dan fasilitas umum.

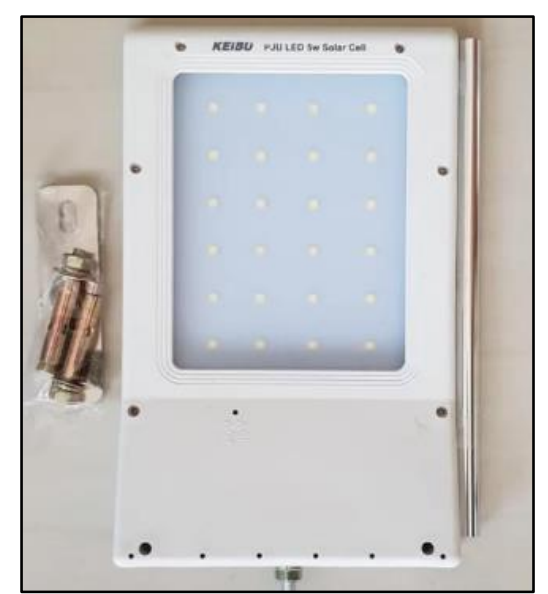

Gambar 3. Lampu Surya KEIBU PJU LED 5W

Sebelum pemasangan lampu, tim PKM menyiapkan tiang lampu PJU berupa tiang besi hollow sepanjang 2,5 meter. Tiap titik dipasang 1 tiang lampu dengan masing-masing tiang terpasang 2 buah lampu. Instalasi lampu pada tiang dibantu warga sekitar. Gambar 4 merupakan foto tiang lampu yang dipasang di jalan depan lapangan umum.

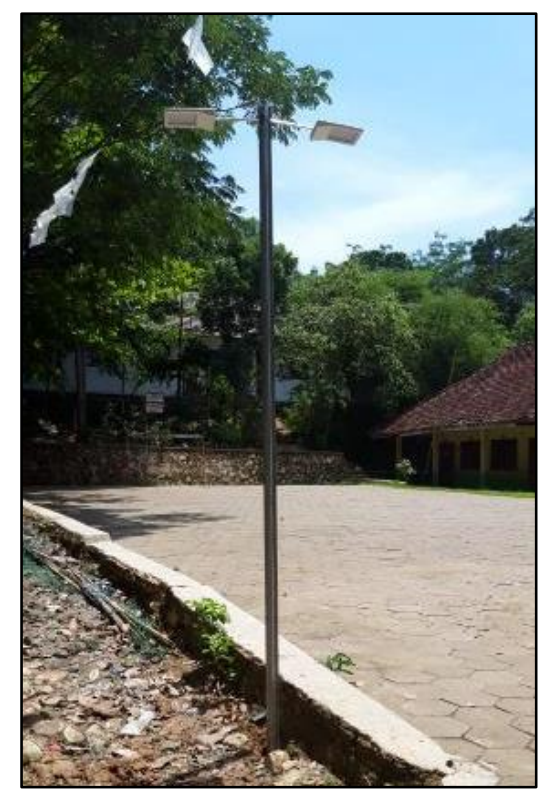


Gambar 4. Lampu Surya yang Terpasang di Jalan Kampung

Selain melakukan pemasangan lampu, tim PKM juga melakukan penyuluhan kepada warga tentang lampu tenaga surya khususnya tentang cara kerja lampu dan penyeleseian ditemui masalah pada lampu tersebut. Warga sangat antusias dengan lampu surya yang dipasang, selain karena warga merasakan manfaat penerangannya, mereka juga tertarik dengan lampu surya tersebut karena ukurannya kecil dan pemasangannya relatif mudah dibanding lampu surya yang pernah mereka lihat. Gambar 5 menunjukkan warga yang mendengarkan penjelasan tim mengenai lampu tenaga surya.

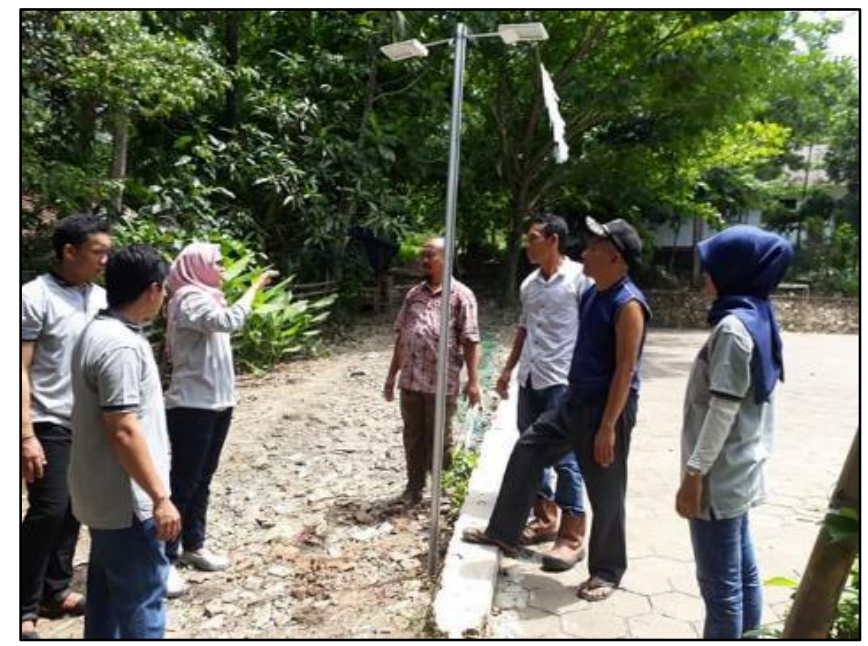

Gambar 5. Warga Mendengarkan Penjelasan Tim tentang Lampu Surya

Pengamatan kinerja lampu surya yang telah terpasang dapat dilakukan saat malam hari, walapun sebelum dipasang, lampu sudah diujicoba fungsionalitasnya. Tim PKM berkoordinasi dengan warga agar warga dapat mengirimkan foto saat lampu beroperasi di malam hari. Komunikasi dilakukan via whatsapp. Selain foto keadaan lampu, tim PKM juga secara aktif memantau kinerja lampu dari hari kehari selama 3 hari. Warga juga diminta untuk menyampaikan keluhan dan masalah yang terjadi berkaitan dengan kinerja lampu surya. Sebagai antisipasi jika salah satu lampu tidak dapat berfungsi, tim PKM memberikan 2 buah lampu cadangan kepada warga. Jadi jika suatu saat lampu rusak, warga dapat menggantinya sendiri dengan lampu surya cadangan

Gambar 6 merupakan foto dari 3 titik pemasangan lampu surya saat lampu beroperasi pada hari pertama setelah lampu tersebut dipasang. Berdasarkan pengamatan warga, semua lampu surya dapat beroperasi dengan baik dan menyala otomatis. Penyinarannya juga cukup terang. Pada saat matahari terbit dan langit mulai terang, lampu secara otomatis dapat padam. Keadaan yang sama ditunjukkan pada hari ke 2. Tetapi pada hari ke-3, cahaya lampu kurang terang karena pada siang harinya matahari tidak terlalu terik akibat terhalang mendung. 

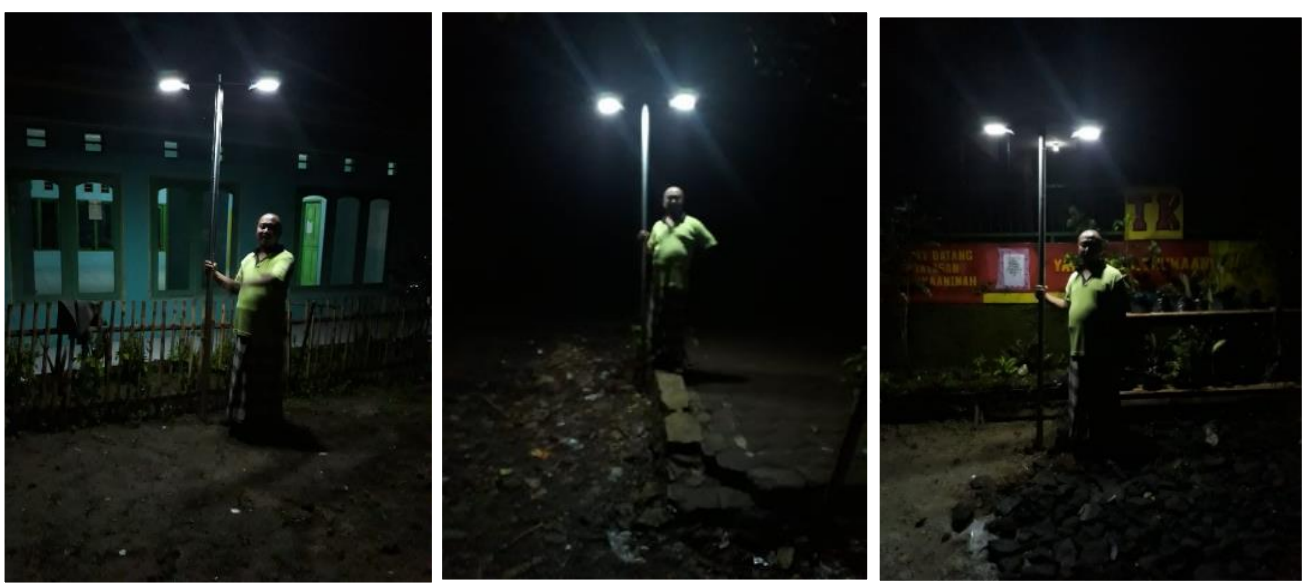

Gambar 6. Lampu Tenaga Surya yang Beroperasi di Malam Hari

\subsection{Analisis Manfaat Ekonomi dari Lampu Tenaga Surya yang Dipasang}

Analisis dari segi ekonomi pada lampu tenaga surya yang terpasang dilakukan untuk melihat manfaat dari sisi ekonomi dibandingkan dengan penggunaan lampu pijar untuk PJU. Selama ini untuk beberapa ruas jalan kampung, warga berinisiatif memasang lampu PJU dengan menarik kabel dari rumah warga. Lampu yang terpasang merupakan lampu pijar karena menurut warga lampu pijar lebih murah daripada lampu LED atau TL. Pada poin ini, akan dianalisis perbandingan dari sisi ekonomi terhadap PJU lampu surya dengan PJU lampu pijar untuk 1 titik lampu selama kurun 3 tahun

Pada tabel 2, dianalisis harga total yang harus dikeluarkan untuk pemakaian PJU lampu pijar, dengan asumsi lampu pijar memerlukan penggantian pada tahun ke 3 dengan harga lampu tetap. Karena lampu PJU memperoleh pasokan listrik dari rumah warga, maka biaya listrik yang diperlukan menyesuaikan Tarif Dasar Listrik untuk rumah tangga tahun 2019 yaitu sebesar Rp 1.467 dengan asumsi tidak ada kenaikan TDL selama 3 tahun ke depan. Jika lampu menyala selama 12 jam, maka kebutuhan listrik perhari adalah:

$W_{\text {pijar harian }}=60 \mathrm{Watt} \times 12 \mathrm{jam}=720 \mathrm{Wh}=0,72 \mathrm{KWh}$

Sedangkan selama 1 tahun, kebutuhan energi listrik untuk menghidupkan 1 lampu PJU adalah:

$W_{\text {pijar tahunan }}=0,72 \mathrm{KWh} \times 365$ hari $=262,8 \mathrm{KWh}$

Biaya listrik yang dikeluarkan selama 1 tahun adalah:

Biaya listrik $=262,8 \mathrm{KWh} \times 1467=R p 385.527,6$

Tabel 2. Analisis Biaya Penggunaan PJU Lampu Pijar

\begin{tabular}{|l|c|c|c|}
\hline \multicolumn{1}{|c|}{ Pengeluaran } & $\begin{array}{c}\text { Tahun ke-1 } \\
(\mathbf{R p})\end{array}$ & $\begin{array}{c}\text { Tahun ke-2 } \\
(\mathbf{R p})\end{array}$ & $\begin{array}{c}\text { Tahun ke-3 } \\
(\mathbf{R p})\end{array}$ \\
\hline Lampu pijar 60 Watt & $9.000,00$ & 0 & $9.000,00$ \\
\hline Tiang besi & $90.000,00$ & 0 & 0 \\
\hline Kap lampu & $30.000,00$ & 0 & 0 \\
\hline Kabel AWG22x2 8 meter & $32.000,00$ & 0 & 0 \\
\hline Biaya listrik 1 tahun & $385.527,60$ & $385.527,60$ & $385.527,60$ \\
\hline Total (pertahun) & $\mathbf{5 4 6 . 5 2 7 , 6 0}$ & $\mathbf{3 8 5 . 5 2 7 , 6 0}$ & $\mathbf{3 9 4 . 5 2 7 , 6 0}$ \\
\hline TOTAL BIAYA (3 tahun) & \multicolumn{3}{|c|}{$\mathbf{R p ~ 1 . 3 2 6 . 5 8 2 , 8 0}$} \\
\hline
\end{tabular}


Pada tabel 3, dianalisis harga total yang harus dikeluarkan untuk pemakaian PJU lampu tenaga surya. Berdasarkan datasheet lampu, lampu PJU LED tenaga surya dapat digunakan selama 5 tahun sebelum akhirnya lampu akan rusak. Sehingga, tidak diperlukan biaya penggantian lampu tenaga surya jika analisis yang dilakukan selama jangka waktu 3 tahun. Agar penyinaran PJU optimal, maka setiap tiang lampu terpasang 2 buah lampu tenaga surya.

Tabel 3. Analisis Biaya Penggunaan PJU Lampu Tenaga Surya

\begin{tabular}{|l|c|c|c|}
\hline \multicolumn{1}{|c|}{ Pengeluaran } & $\begin{array}{c}\text { Tahun ke-1 } \\
(\mathbf{R p})\end{array}$ & $\begin{array}{c}\text { Tahun ke-2 } \\
(\mathbf{R p})\end{array}$ & $\begin{array}{c}\text { Tahun ke-3 } \\
(\text { Rp })\end{array}$ \\
\hline $\begin{array}{l}\text { Lampu KEIBU PJU LED } \\
2 \text { buah }\end{array}$ & $600.000,00$ & 0 & 0 \\
\hline Tiang besi & $90.000,00$ & 0 & 0 \\
\hline Total (pertahun) & $\mathbf{6 9 0 . 0 0 0 , 0 0}$ & $\mathbf{0}$ & $\mathbf{0}$ \\
\hline \multicolumn{3}{|c|}{ TOTAL BIAYA (3 tahun) } & \multicolumn{3}{|c|}{. } \\
\hline
\end{tabular}

Berdasarkan hasil analisis pada tabel 2 dan 3, diperoleh perbedaan total biaya yang besar untuk pengoperasian kedua PJU selama 3 tahun. Untuk pengoperasian PJU lampu pijar selama 3 tahun, diperlukan biaya sebesar Rp 1.326.582,80. Sedangkan PJU lampu surya hanya memerlukan biaya Rp 690.000,00. Sebagian besar biaya PJU lampu pijar digunakan untuk membayar biaya listrik. Walaupun harga lampu PJU tenaga surya lebih mahal, tetapi untuk penggunaan jangka panjang, PJU lampu tenaga surya jauh lebih ekonomis dibandingkan PJU lampu pijar, dengan selisih biayanya adalah sebesar Rp 636.582,80 untuk jangka waktu 3 tahun.

\section{KESIMPULAN}

Kegiatan Program Kemitraan Masyarakat (PKM) mengenai Pemanfaatan Energi Surya untuk Penerangan Jalan \& Fasilitas Umum di Desa Sukarame, Kab. Lebak, Banten telah berhasil dilaksanakan pada tanggal 17 November 2018. Kegiatan tersebut berupa pemasangan lampu Penerangan Jalan Umum (PJU) dengan memanfaatkan tenaga surya. Lampu yang digunakan adalah lampu merk KEIBU LED PJU 5 watt. Pada bagian atas lampu terdapat panel surya sebesar 5 Watt. Lampu juga memiliki sistem penyalaan otomatis dengan mendeteksi cahaya sekitar dan baterai tertanam sebesar $2000 \mathrm{mAh}$. Sebelum lampu tersebut dipasang, tim PKM melakukan survei lapangan untuk menentukan titik-titik pemasangan lampu. Diperoleh 3 titik pemasangan lampu yang strategis yaitu di jalan kampung depan TK, jalan kampung depan lapangan, dan teras mushola warga.

Pemasangan lampu telah berhasil dilakukan. Lampu dapat beroperasi dengan baik pada malam hari. Analisis kinerja lampu tenaga surya juga ditinjau dari segi ekonomi dengan cara membandingkan total pengeluaran yang diperlukan untuk lampu PJU tenaga surya dan PJU yang menggunakan lampu pijar dengan sumber listrik dari rumah warga. Berdasarkan hasil perhitungan, pengoperasian PJU lampu pijar selama 3 tahun, memerlukan biaya sebesar Rp 1.326.582,80. Sedangkan PJU lampu surya hanya memerlukan biaya Rp 690.000,00. Sebagian besar biaya PJU lampu pijar digunakan untuk membayar biaya listrik. Walaupun harga lampu PJU tenaga surya lebih mahal, tetapi untuk penggunaan jangka panjang, PJU lampu tenaga surya jauh lebih ekonomis dibandingkan PJU lampu pijar, dengan selisih biayanya sebesar Rp 636.582,80 untuk pemakaian jangka waktu 3 tahun. 


\section{SARAN}

Saran yang dapat diberikan untuk program sosisalisasi ini adalah pemasangan lampu PJU tenaga surya dengan kapasitas yang lebih besar sehingga penyinaran yang diperoleh juga lebih optimal.

\section{UCAPAN TERIMA KASIH}

Penulis mengucapkan terima kasih kepada STT-PLN Jakarta dan LPPM atas kesempatan kepada tim PKM dan dukungan baik moril maupun materiil serta pendanaan sehingga kegiatan PKM dapat terlaksana dengan baik.

\section{DAFTAR PUSTAKA}

[1] Kementerian ESDM. 2018. Executive Summary RUPTL PT.PLN (Persero) 2018-2027 pada acara Diseminasi RUPTL 2018-2027. (https://www.esdm.go.id/assets/media/content/contentringkasan-ruptl-2018-2027.pdf, diakses online tanggal 9 Januari 2019)

[2] Jaelani, A. 2017. Energi Baru Terbarukan Di Indonesia: Isyarat Ilmiah Al-Qur'an Dan Implementasinya Dalam Ekonomi Islam. University Library of Munich, Jerman.

[3] PT. PLN (PERSERO). 2018. RUPTL PT.PLN (PERSERO) 2018-2027. (http://www.djk.esdm.go.id/pdf/RUPTL/03\%20-\%2022\%20-\%202018\%20RUPTL\%202018 - 2027\%20PLN.pdf, diakses online tanggal 11 Februari 2019)

[4] Rifa'i, Bahtiar. 2017. Kebutuhan Pasokan Listrik Banten Sudah Mendesak. (https://finance.detik.com/energi/d-3573356/kebutuhan-pasokan-listrik-banten-sudahmendesak, diakses online tanggal 7 Februari 2019)

[5] Sugiyono, Agus, et al. 2017. Analisis Spasial dari Pola Kebutuhan Listrik di Provinsi Banten: Aplikasi Metodologi Berbasis Sistem Informasi Geografis. Seminar Nasional Integrasi Proses 2017. Cilegon, Banten.

[6] Manan, Saiful. 2009. Energi Matahari, Sumber Energi Alternatif Yang Effisien, Handal dan Ramah Lingkungan di Indonesia. Gema Teknologi.

[7] Widayana, G. 2012. Pemanfaatan Energi Surya. Jurnal Pendidikan Teknologi dan Kejuruan, 9(1). 